\title{
Dendritic-Cell Specific Antigen HIV1: Novel Terapi Berbasis Biomolekuler sebagai Imunomodulator pada Penderita HIV Tipe 1
}

(Dendritic-cell specific antigen HIV-1: novel biomolecular based therapy as immunomodulator on type 1 HIV patient)

\author{
Albert Salim*, Maria Pramesthi Sabrina Evananda, Aizar Vesa Prasetyo \& \\ I Gusti Made Gde Surya Chandra Trapika \\ Fakultas Kedokteran Universitas Udayana, JI. P.B. Sudirman, Dangin Puri Klod, Kec. Denpasar Bar., Kota Denpasar, Bali
}

\begin{abstract}
Human Immunodeficiency Virus (HIV) infection, either type 1 which is spread worldwide or type 2 which is more isolated in Africa, is still a challenge in the world health sector, including Indonesia. This high HIV rate is important to treat because of the dangers of complications that lurk. The current management and treatment of HIV with the use of antiretrovirals has limitations in terms of therapeutic effects and side effects. The development and discovery of therapeutic modalities that have the potential for a more optimal therapeutic effect is a challenge that continues to be pursued in the treatment of HIV. One of them is the development of dendritic cell-based immunotherapy. This literature review was written systematically on the study reports related to the above from various sources including Google Scholar, PubMed, Research Gate to describe the potential of dendritic cells as immunomodulators in HIV-1 patients. This immunotherapy modality is constructed in the form of a dendritic cellbased vaccine, a cell that plays a role in HIV pathogenesis, which is administered intradermally. The vaccine given will stimulate an immune response and can be used not only as a therapeutic effort in patients but has the potential to be used as prevention.

Keywords: dendritic cell; type 1 HIV; immunotherapy; dendritic cell-based vaccine;
\end{abstract}

ABSTRAK: Infeksi Human Immunodeficiency Virus (HIV), baik tipe 1 yang tersebar ke seluruh dunia maupun tipe 2 yang terisolasi di Afrika, masih menjadi tantangan di bidang kesehatan dunia termasuk Indonesia. Angka HIV yang tinggi ini penting untuk ditangani karena bahaya komplikasi yang mengintai. Penatalaksanaan dan terapi HIV yang ada saat ini dengan penggunaan antiretroviral memiliki keterbatasan dilihat dari efek terapi dan efek samping yang ditimbulkan. Pengembangan dan penemuan modalitas terapi yang memiliki potensi efek terapi yang lebih optimal merupakan suatu tantangan yang terus diupayakan dalam penanganan HIV ini. Salah satunya adalah pengembangan imunoterapi berbasis sel dendritik. Literature review ini ditulis secara sistematis mengenai laporan studi terkait hal di atas dari berbagai sumber termasuk Google Scholar, PubMed, Research Gate untuk menguraikan potensi sel dendritik sebagai imunomodulator pada penderita HIV-1. Modalitas imunoterapi ini dikonstruksi dalam bentuk vaksin berbasis sel dendritik, sel yang berperan pada patogenesis HIV, yang diadministrasikan secara intradermal. Vaksin yang diberikan akan menstimulasi respon imun dan dapat digunakan tidak saja sebagai upaya terapi pada penderita tapi berpotensi digunakan sebagai pencegahan.

Kata kunci: sel dendritik; HIV tipe 1; imunoterapi; vaksin berbasis sel dendritik;

\section{Pendahuluan}

Infeksi Human Immunodeficiency Virus (HIV) merupakan salah satu penyakit yang masih menjadi tantangan dunia. HIV memiliki dua tipe, yaitu HIV tipe 1 yang menyebar di seluruh dunia dan HIV tipe 2 dengan distribusi terutama di Afrika Barat. [1] Epidemi HIV terus berkembang secara global di 45 negara termasuk Indonesia dengan kasus baru HIV yang bertambah sekitar 48.000 kasus per tahun 2017 dan rerata prevalensi kasus di Indonesia sebesar 0,41\%. Permasalahan yang sama juga dialami negara lain, dengan estimasi jumlah penderita HIV di seluruh dunia pada akhir tahun 2019 yaitu sebanyak 38 juta kasus [2]. Kasus HIV yang dimulai pada tahun 1981 menunjukkan peningkatan setiap tahun dengan peningkatan sebesar 19.93\% dari tahun 1997 hingga 2015 [3].

Infeksi HIV dimulai dari kontak dengan darah atau cairan tubuh individu terinfeksi melalui hubungan seksual, parenteral, perinatal atau melalui menyusui. Tingkat virus HIV yang bersirkulasi pada orang terinfeksi meningkat tidak lama setelah infeksi, akibat replikasi sel yang

\section{Article history}

Received: 05 Juli 2021 Accepted: 21 Nov 2021 Published: 07 Des 2021

Access this article

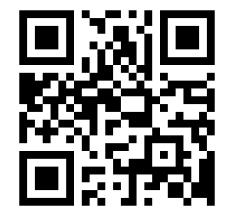


cepat. Pasien pada periode ini dapat menunjukkan gejala infeksi HIV primer. Antibodi spesifik akan berkembang dan tingkat virus menurun mencapai keadaan stabil, sehingga umumnya pasien tidak menunjukkan gejala atau asimtomatik selama beberapa tahun. Jumlah limfosit CD4 menurun secara bertahap seiring waktu akibat pembunuhan virus, apoptosis dan aktivasi limfosit CD8. Tingkat CD4 akhirnya menurun mencapai suatu titik saat cell-mediated immunity terpengaruh dan orang terinfeksi menjadi rentan untuk mengalami infeksi oportunistik seperti tuberkulosis, mengalami nefropati terkait HIV, demensia dan kanker [1]. HIV juga dapat menimbulkan gangguan psikososial akibat adanya stigmatisasi masyarakat terhadap penderita yang berpengaruh pada kualitas hidup [4].

Pengobatan HIV berdasarkan Peraturan Menteri Kesehatan Republik Indonesia nomor 21 tahun 2013 meliputi pengobatan HIV dengan cara pengobatan terapeutik, profilaksis dan penunjang yang dilakukan bersamaan dengan penapisan dan terapi infeksi oportunistik, pemberian kondom dan konseling. Pengobatan terapeutik yang dimaksudkan meliputi pengobatan dengan antiretroviral (ARV), pengobatan infeksi menular seksual dan pengobatan infeksi oportunitis, sementara pengobatan profilaksis meliputi pemberian ARV pasca pajanan dan kotrimoksasol untuk terapi dan profilaksis. Pengobatan penunjang juga diberikan pada pasien HIV, berupa pengobatan suportif, adjuvant dan perbaikan gizi [5].

Obat ARV yang dikonsumsi seumur hidup meningkatkan harapan hidup pasien HIV, tetapi tidak terlepas dari efek toksisitas yang ditimbulkan. Efek samping jangka pendek yang umum dialami pasien yang mengkonsumsi ARV meliputi mual, diare, kembung dan masalah kulit. Pasien yang mengonsumsi ARV jangka panjang memiliki resiko untuk mengalami fraktur, osteoporosis, gangguan pada ginjal, hepar, sistem saraf pusat, jantung dan pembuluh darah [6]. Masalah lain dalam mencapai keberhasilan tatalaksana HIV adalah kepatuhan pasien dalam mengkonsumsi obat, karena ketidakpatuhan pasien berdampak negatif pada hasil pengobatan, berupa ketidakefektifan supresi virus dan risiko resistensi terhadap kelompok obat tertentu. Adapun, jumlah dan jenis regimen pengobatan yang kompleks, efek samping pengobatan, minimnya pengetahuan pasien dan pendamping, serta pengaruh sosial seperti diskriminasi dan stigmatisasi merupakan penghalang untuk mencapai pengobatan HIV yang efektif [7].

Penatalaksanaan HIV yang ada saat ini dengan segala keterbatasan yang dimilikinya telah mendorong upayaupaya penemuan obat baru melalui berbagai pendekatan.
Salah satunya adalah dengan upaya memodulasi sistem kekebalan tubuh yang dikenal sebagai imunoterapi. Konsep terapi ini mulai dikenal dari pengobatan kanker dan saat ini juga berkembang untuk menangani penyakit infeksi, termasuk HIV [8]. Prosedur ini bertujuan menstimulasi sistem kekebalan tubuh agar sistem kekebalan tubuh mengenali antigen yang dimasukkan serta mampu memberi perlawanan pada saat terkena penyakit tersebut sehingga memberikan efek proteksi. Adapun, dalam keseluruhan studi saat ini, pasien diberikan vaksin sebagai terapi, sehingga dalam konteks ini, vaksin tidak berperan sebagai pencegahan. Vaksinasi HIV terus dikembangkan hingga saat ini, tetapi masih terkendala berbagai faktor salah satunya adalah tingginya laju mutasi virus [9]. Salah satu modalitas dalam pendekatan ini adalah penggunaan sel dendritik sebagai komponen dasar dan utama vaksin HIV. Sel yang memiliki peranan yang krusial di dalam patogenesis HIV ini dapat memicu respon dari sel $\mathrm{T}$ CD8 dan CD4 apabila dimasukkan ke dalam tubuh [10]. Sel dendritik juga akan merangsang berbagai sel imun lain, sehingga pengembangan vaksin ini memungkinkan replikasi virus terkontrol tanpa pengobatan antiretroviral [11].

Literature review ini bertujuan untuk mengkaji sel dendritik sebagai komponen dasar vaksin HIV. Metode ini memberikan peluang besar bagi perkembangan vaksin sebagai terapi HIV yang diharapkan mampu membantu proses perbaikan pasien HIV.

\section{Metode Penelitian}

Penelusuran literatur dilakukan pada tanggal 12 Januari-5 Februari 2021 di tiga basis data ilmiah online, yaitu PubMed, Google Scholar dan Research Gate dengan menggunakan kata kunci yaitu, "sel dendritik", HIV tipe 1", “imunoterapi", "vaksin berbasis sel dendritik". Kriteria inklusi yang digunakan pada kajian literatur ini adalah penelitian uji klinik dengan subjek penelitian yaitu pasien HIV tipe 1. Studi literatur dilanjutkan dengan melakukan skrining terhadap sumber yang sesuai dan relevan, sehingga didapatkan 40 yang sesuai, yaitu 26 dari PubMed, 6 dari Research Gate, 8 dari Google Scholar. Seluruh jurnal yang diperoleh ditelaah secara kritis dari segi validitas, importance, dan applicability-nya.

\section{Hasil dan Diskusi}

\section{Patogenesis Human Immunodeficiency Virus (HIV)}

HIV merupakan virus dari famili Retroviridae yang 
dapat ditransmisikan melalui cairan tubuh dari orang yang telah terinfeksi sebelumnya, termasuk melalui darah, air susu ibu (ASI), cairan semen maupun sekresi dari vagina saat berhubungan seksual ataupun dari ibu ke bayinya selama proses kehamilan ataupun saat kelahiran (HIV/AIDS, 2021). HIV sendiri secara spesifik menyerang limfosit $\mathrm{T} \mathrm{CD} 4^{+}$melalui interaksi dengan CD4 dan koreseptor kemokin yang diekspresikan yaitu C-C Chemokine Receptor type 5 (CCR5) terutama sel T memori [12]. HIV mereplikasi diri di jaringan limfoid dimana banyak terdapat limfosit $\mathrm{T}$ $\mathrm{CD}^{+}$dan terdistribusi melalui darah [13-15]. HIV yang menyerang sel limfosit $\mathrm{T}$ CD $4^{+}$menyebabkan degradasi jumlah sel limfosit $\mathrm{T} \mathrm{CD}^{+}$secara bertahap terutama di situs mukosa sehingga terjadi defisiensi sel imun secara progresif. Sel limfosit T $\mathrm{CD}^{+}{ }^{+}$sendiri merupakan bagian dari sel darah putih yang berperan dalam sistem imun. Hal ini kemudian diikuti pula dengan perkembangan virus yang telah berevolusi dengan menginfeksi sel $\mathrm{T} \mathrm{CD}^{+}$naif yang secara struktural memiliki kadar CD4 yang lebih rendah pada permukaan selnya melalui interaksi dengan koreseptor C-X-C Chemokine Receptor type 4 (CXCR4) [16]. Hal inilah kemudian yang menyebabkan HIV sampai sekarang sulit untuk ditekan aktivitasnya karena secara langsung HIV telah menyerang baik imunitas bawaan maupun adaptif dari pasien terinfeksi HIV. Virus HIV yang terus berevolusi inilah kemudian yang memungkinkan infeksi oportunistik lainnya menginfeksi seperti infeksi Herpes Simples Virus-1 (HSV-1), kandidiasis, dan juga toksoplasmosis [17].

Infeksi HIV secara langsung menyebabkan penurunan jumlah sel $\mathrm{CD}^{+}$secara progresif akibat penurunan produksi dan peningkatan kerusakan. Pada tahap awal, terjadi penurunan sementara pada sel $\mathrm{T} \mathrm{CD}^{+}$ yang tersirkulasi diikuti oleh pemulihan ke konsentrasi yang mendekati normal, yang kemudian secara bertahap menurun perlahan-lahan sekitar $50-100 \mathrm{sel} / \mathrm{mm}^{3}$ hingga mencapai batas kurang dari $200 \mathrm{sel} / \mathrm{mm}^{3}$ dimana pasien terdiagnosis sebagai Acquired Immune Deficiency Syndrome (AIDS) atau berada pada tahap 3 infeksi HIV [18]. Penurunan lainnya juga terjadi pada subset sel $\mathrm{T}$ termasuk preferensial sel T-helper-17, 61 dan sel limfosit $\mathrm{T}$ di mukosa intestinal terutama di lapisan sel epitel dan lamina propia yang berperan penting untuk mempertahankan saluran gastrointestinal dari patogen terutama bakteri gram negatif yang memiliki lipopolisakarida pada bagian selubungnya yang bersifat endotoksin dan memicu inflamasi [12]. Secara garis besar terjadi penipisan sel limfoid yang dalam saluran pencernaan, bersama dengan apoptosis enterosit, dan peningkatan permeabilitas saluran pencernaan, penghancuran jaringan sel retikuler fibroblastik yang membentuk jaringan kelenjar getah bening, deposisi kolagen, dan akses terbatas ke faktor kelangsungan hidup sel T interleukin 7 (IL-7) dalam jaringan limfoid selanjutnya [12].

\section{Peran Sel Dendritik dalam Patogenesis HIV}

Sel dendritik (DC) merupakan salah satu antigenpresenting cells (APCs) yang berasal dari sel induk CD34 ${ }^{+}$ tulang sumsum dan terbentuk dari hematopoiesis limfomyeloid sehingga menghubungkan imunitas bawaan dan imunitas adaptif. Sel ini dapat ditemukan di darah, jaringan, dan organ limfoid. Dalam sistem imun bawaan, sel dendritik berfungsi mengenali dan merespon pathogen serta sinyal bahaya sehingga terjadi respons berupa inflamasi akut. Sedangkan pada sistem imun adaptif, sel dendritik berperan dalam memproses protein intraseluler dan ekstraseluler serta mempersembahkan antigen dalam bentuk molekul major histocompatibility complex (MHC) ke sel limfosit $T$ naif [19].

Fungsi utama dari sel dendritik (DC) adalah sebagai APC melalui proses fagositosis, mencerna dan mempersentasikan antigen bersama MHC ke sel imun adaptif dalam hal ini sel limfosit $\mathrm{T}$ naif lalu terdeviasi polarisasinya menjadi sel efektor. Secara sederhana sel dendritik memiliki peran penting dalam memediasi respon imun bawaan dan menginduksi respon imun adaptif serta diakui sebagai antigen-presenting cells (APCs) yang berasal dari sel induk $\mathrm{CD}^{+} 4^{+}$di sumsum tulang [19]. Sebagai penghubung antara imunitas bawaan dan adaptif, sel dendritik memiliki peran yang esensial terhadap infeksi HIV dimana sel dendritik menginduksi limfosit T-helper khusus HIV yaitu CD4+ sebagai reseptor dan CCR5 serta CXCR4 sebagai koreseptor yang berperan penting untuk mencapai limfosit $\mathrm{T}$ sitotoksik $\mathrm{CD}^{+}$khusus HIV yang persisten dan efektif untuk mengendalikan replikasi HIV [20].

Sel dendritik dibagi menjadi dua subtipe utama yaitu Plasmacytoid Dendritic-Cells (pDCs) dan Myeloid DendriticCells (mDCs), baik pDCs maupun mDCs berasal dari sel progenitor yang berbeda dan memliki fungsi yang berbeda pula [21]. Sel dendritik myeloid sendiri berfungsi untuk mengatur respons pro-inflamasi melalui induksi sel T-helper 1 dan respon limfosit $\mathrm{T}$ sitotoksik pada infeksi bakteri maupun virus. Sedangkan sel dendritik plasmacytoid menghasilkan interferon tipe I dan tipe II (IFN-1 dan IFN-2) sebagai respon terhadap infeksi patogen dalam bentuk untaian RNA tunggal dan untaian ganda DNA yang kemudian akan dikenali oleh Toll-Like Receptor (TLR), yang terdapat di permukaan sel dendritik tersebut, C-type Lectin, dan sensor asam nukleat intraseluler yang dimediasi aktivasinya oleh patogen [22]. Sel progenitor dari sel 
dendritik sendiri terlokalisasi di sumsum tulang dan berkembang menjadi pro-sel dendritik pada saat memasuki dan termaturasi di aliran darah serta berdiferensiasi secara terminal menginduksi limfosit T-helper $\mathrm{CD}^{+}$dan $\mathrm{CD}^{+}$di kelenjar getah bening perifer [23].

Penelitian terbaru menunjukkan proses masuknya HIV ke dalam sel tubuh melalui dynamin-dependent endocytosis yang mana sebelumnya HIV menginfeksi sel tubuh melalui fusi membran setelah adanya binding dengan reseptor CCR5 dan koreseptor CXCR4 [24]. Proses ini terjadi di permukaan sel dan bergantung pada level dari CD4 yang diekspresikan oleh sel tersebut. Level CD4 yang rendah akan melimitasi fusi HIV ke dalam sel. Pada fase ini sel dendritik yang berperan sebagai APC akan mengenali HIV berdasarkan spike protein gp120 yang berikatan dengan $\mathrm{CD}^{+}$dan memodulasi sel $\mathrm{T}$ sitotoksik spesifik HIV [25]. Sel dendritik kemudian berfungsi sebagai transport yang membawa HIV dengan berkembangnya endosom menjadi multivesicular bodies (MVBs) dan akan melalui tahap fusi lisosomal dan degradasi Ag sehingga dapat dipersembahkan ke MHC. Dengan menargetkan HIV untuk dikenali lebih efisien oleh MHC maka respon imun yang diberikan tubuh dapat lebih efisien dan efektif. Hal ini kemudian yang membuat sel dendritik memiliki kemampuan untuk menghambat replikasi virus HIV [26].

\section{Mekanisme Konstruksi Vaksin Berbasis Sel Dendritik}

Vaksin berbasis sel dendritik ini menggunakan konsep efisiensi vaksin berbasis virus dengan menghubungkan protein dengan ligan Pattern Recognition Receptor (PRR) untuk menghasilkan vaksin konjugasi antigen-PRR-ligan dimana antigen dapat diproses dan distimulasi dalam waktu yang bersamaan pada sel dendritik yang sama pula. Antigen yang digunakan tergantung dari patogen yang ditargetkan dimana dalam hal ini adalah HIV-1 p24 gag (gag: group specific antigen), sedangkan untuk pemilihan antibodi atau ligan PRR sendiri bergantung pada respon imun yang diinginkan dan profil ekpresi PRR yang ditargetkan oleh sel dendritik ini dimana dalam hal ini adalah ligan Toll-like Receptor (TLR) [27]. Vaksin konjugasi ligan antigen-TLR sampai saat ini menunjukkan hasil yang positif yang secara efisien menghasilkan respon imun adaptif. Pemilihan HIV1 p2 $^{\text {gag }}$ sebagai antigen didasari beberapa faktor yang menguntungkan sebagai vaksin yang stabil dan aman. Partikel kapsid yang menyelubungi inti HIV ini, merupakan struktur virus yang tidak mudah mengalami mutasi dan tidak mengandung komponen hidup HIV tetapi cukup kuat untuk merangsang pembentukan imunitas terhadap virus ini [28].

Langkah awal adalah dengan mengisolasi virus dan diamplifikasi dari serum pasien terinfeksi untuk kemudian dikarakterisasi secara molekuler untuk persiapan konstruksi gen pengkode protein subunit rekombinan. Dari proses ini didapatkan antigen yang dibutuhkan untuk vaksin yaitu HIV-1 p24 gag [29]. Kemudian pengambilan sampel sel dendritik terutama monosit dari pasien yang dinyatakan positif terinfeksi HIV dengan pertimbangan sel dendritik yang sudah mengalami kontak dengan antigen akan mengalami pematangan dan bermigrasi ke kelenjar getah bening pada regio yang sama. Selain itu sel dendritik yang diturunkan dari monosit memungkinkan diferensiasi secara penuh dan bersifat homogen serta dapat menginduksi sistem imun yang efisien. Sel dendritik yang masih belum matang ini dapat menangkap HIV1 p $4^{\text {gag }}$ dan mendegradasi antigen tersebut sampai ke tingkat peptida dan dibawa ke permukaan sel oleh molekul Major Histocompatibility Complex (MHC) [30]. Setelah itu sel dendritik yang belum matang akan memasuki proses pematangan kompleks melalui reseptor TLR dan meregulasi reseptor kemokin C-C tipe 7 (CCR7) yang

Tabel 1. Uji klinik imunoterapi HIV berbasis sel dendritik

\begin{tabular}{|c|c|c|c|c|}
\hline Target studi & Metodologi & $\begin{array}{c}\text { Jumlah } \\
\text { partisipan }\end{array}$ & Parameter & Referensi \\
\hline $\begin{array}{l}\text { Frekuensi resting } \mathrm{CD} 4+T \text { cell } \\
\text { infection }(\mathrm{RCI})\end{array}$ & $\begin{array}{l}\text { Pemberian vaksin dilakukan sebanyak } \\
5 \text { kali secara intradermal pada min- } \\
\text { ggu ke- } 0,4,8,12,16\end{array}$ & 6 pasien & $\begin{array}{l}\text { Penurunan } \mathrm{RCl} \text { pada partisipan menunjukkan } \\
\text { jumlah infectious unit yang berkurang }\end{array}$ & [38] \\
\hline Kerja sitokin IL-10 dan IL-12p70 & $\begin{array}{l}\text { Pemberian vaksin dilakukan sebanyak } \\
3 \text { kali di lengan }\end{array}$ & 17 pasien & $\begin{array}{l}\text { Penurunan kapasitas migrasi dan sekresi } \\
\text { sitokin IL-10 dan IL-12p70 }\end{array}$ & [39] \\
\hline $\begin{array}{l}\text { CD28+/ CD45A-, CD8+ memory } \\
\text { cytotoxic T-lymphocytes (CTL) }\end{array}$ & $\begin{array}{l}\text { Pemberian vaksin dilakukan sebanyak } \\
4 \text { kali setiap } 3 \text { minggu secara intra- } \\
\text { dermal }\end{array}$ & 12 pasien & $\begin{array}{l}\text { CD28+/CD45RA- CD8+ memory CTL meningkat } \\
2 \text { kali dari baseline menunjukkan respon imun } \\
\text { positif }\end{array}$ & [40] \\
\hline $\begin{array}{l}\text { Plasma viremia, hypermutant } \\
\text { gag and pol }\end{array}$ & $\begin{array}{l}\text { Pemberian vaksin dilakukan sebanyak } \\
4 \text { kali }\end{array}$ & 10 pasien & $\begin{array}{l}\text { Penurunan plasma viremia secara signifikan } \\
\text { dan peningkatan G>A hypermutant yang men- } \\
\text { unjukkan sitolisis sel yang terinfeksi }\end{array}$ & [36] \\
\hline
\end{tabular}


menginduksi sel dendritik matang ke dalam aliran darah ke organ limfoid perifer atau melalui pembuluh limfatik ke kelenjar getah bening [30].

\section{Mekanisme Administrasi}

Vaksin HIV berbasis sel dendritik akan diadministrasikan secara intradermal. Hal ini didasarkan pada fakta bahwa pada bagian dermis sendiri terkandung lebih banyak seldendritikyangakan membantu memfasilitasi penangkapan antigen serta respon peradangan lokal yang menginduksi pematangan sel dendritik migrasinya ke kelenjar getah bening [31]. Hal ini pun meningkatkan efisiensi migrasi sel dendritik menuju organ limfoid dan respon imun yang didapat lebih maksimal dibandingkan mekanisme administrasi lainnya seperti subkutan dan intravena [32]. Berdasarkan pernyataan tersebut, maka volume yang diperlukan untuk injeksi intradermal pun lebih sedikit dibandingkan administrasi subkutan dan intravena [31]. Meski demikian diperlukan penelitian lebih lanjut mengenai dosis dan jangka waktu untuk sekali pemberian agar dapat memberikan efek yang optimal.

\section{Mekanisme Kerja}

Vaksin berbasis sel dendritik berisi sel dendritik imatur yang mengandung antigen HIV-1. Setelah diadministrasikan secara intradermal, sel dendritik akan migrasi ke organ limfoid sekunder seperti nodus limfa, untuk menjalani maturasi dan menstimulasi respon imun. Sel dendritik yang sudah matang akan mempresentasikan antigen HIV-1 ini pada sel $\mathrm{T}$ naif pada organ limfoid dan meningkatkan regulasi major histocompatibility complex (MHC) kelas I dan II serta molekul kostimulator seperti B7.1 dan B7.2 [21]. Hal ini penting untuk aktivasi sel T naif karena memerlukan persinyalan interaksi reseptor sel $\mathrm{T}$ spesifik antigen dan sinyal kedua yang dimediasi oleh B7 / CD28 kostimulator [33]. Selain itu, molekul adhesi seperti intercellular adhesion molecule-1 dan lymphocyte functionassociated antigen 1 juga diekspresikan oleh sel dendritik dan mendorong interaksi sel ke sel yang berkepanjangan. Interaksi tersebut memungkinkan sel $T$ naif berdiferensiasi menjadi sel efektor. Aktivasi sel T naif oleh sel dendritik menyebabkan ekspansi klonal serta diferensiasi sel $\mathrm{T}$ helper (CD4+), sel $\mathrm{T}$ regulator, dan sel $\mathrm{T}$ sitotoksik (CD8+) yang spesifik HIV-1 [30]. Sel CD4+ spesifik HIV yang mensekresikan IL-2 dan sel CD8+ spesifik gag yang mengekspresikan perforin akan menekan infeksi virus HIV [34]. IL-2 yang disekresi dapat menstimulasi diferensiasi sel $\mathrm{T}$ menjadi sel $\mathrm{T}$ efektor dan sel $\mathrm{T}$ memori, sehingga meningkatkan respon imun tubuh terhadap virus [35].

Selain stimulasi sel $T$, sel dendritik mampu menstimulasi sel B di nodus limfa dan pusat germinal. Antigen yang ditangkap oleh FcR $\gamma$ IIB dapat disimpan dalam vesikula intraseluler dan dipresentasikan ke sel B. Sel dendritik juga memodulasi fungsi sel natural killer dan sel T sitotoksik sehingga menimbulkan respon imun untuk virus HIV-1 [30].

Vaksin berbasis sel dendritik ini akan menjadi salah satu imunoterapi untuk penderita HIV/AIDS untuk meningkatkan sistem imun pasien [36]. Pengenalan antigen oleh sel dendritik pada pasien HIV mengalami gangguan, dimana virus HIV-1 memanfaatkan sel dendritik untuk ditransfer ke sel CD4+. Transfer ini merupakan mekanisme penyebaran HIV-1 yang disebut trans-infeksi dan terjadi tanpa adanya infeksi sel dendritik yang produktif. Pemberian vaksin berupa sel dendritik dengan antigen HIV-1 dapat memberikan presentasi antigen yang efektif, sehingga memperbaiki gangguan fungsi sel CD4+ dan sel CD8+ dan mencegah lolosnya virus dari sel T sitotoksik [37].

Uji klinik terkait imunoterapi berbasis sel dendritik sampai saat ini masih memiliki keterbatasan dan melibatkan sedikit sampel, seperti yang tercantum dalam Tabel 1. Selain itu, belum ada studi yang melaporkan pemanfaatan modalitas sel dendritik ini sebagai pencegahan. Oleh karena itu, uji lebih lanjut terkait efektivitas, efek samping dan potensi pengembangan modalitas ini sebagai pencegahan perlu untuk dilakukan.

\section{Kesimpulan}

Infeksi HIV merupakan penyakit infeksi yang masih menjadi epidemi hingga saat ini. Penatalaksanaan HIV masih belum efektif karena faktor agen, host dan juga lingkungan. Imunoterapi HIV berbasis sel dendritik memberikan potensi pengembangan pengobatan HIV melalui stimulasi pada sistem imun dengan efek samping minimal. Namun, uji klinik terkait imunoterapi ini masih sangat terbatas dan menggunakan sampel yang sedikit sehingga perlu dilakukan uji lebih lanjut terkait efektivitas, efek samping dan potensi dari modalitas ini untuk dikembangkan sebagai pencegahan.

\section{Referensi}

[1]. Melhuish A, Lewthwaite P. Natural history of HIV and AIDS. Medicine (Baltimore). 2018;46(6):356-61. https://doi.org/10.1016/J. MPMED.2018.03.010

[2]. Riono P, Challacombe SJ. HIV in Indonesia and in neighbouring countries and its social impact. Oral Dis. 2020; https://doi. org/10.1111/odi.13560

[3]. Raya HB. Global and National trends of HIV/AIDS. Res Rev Insights. 2018; https://doi.org/10.15761/rri.1000134 
[4]. HaryantiT, Wartini. Perception of people living with HIV/AIDS on social stigma of HIV/AIDS in Sukoharjo District. Kesmas. 2019;13(3):132-7. https://doi.org/10.21109/kesmas.v13i3.1752

[5]. Menteri Kesehatan Republik Indonesia. Permenkes No. 21 Tahun 2013 Penanggulangan HIVAIDS. 2013;

[6]. Chawla A, Wang C, Patton C, Murray M, Punekar Y, de Ruiter A, et al. A Review of Long-Term Toxicity of Antiretroviral Treatment Regimens and Implications for an Aging Population [Internet]. Vol. 7, Infectious Diseases and Therapy. Springer Healthcare; 2018. p. 183-95. https://doi.org/10.1007/s40121-018-0201-6

[7]. Schaecher KL. The importance of treatment adherence in HIV. American Journal of Managed Care. 2013.

[8]. Jessica Eno MS P-C. Immunotherapy Through the Years. J Adv Pract Oncol. 2017; https://doi.org/10.6004/jadpro.2017.8.7.8

[9]. Robinson HL. HIV/AIDS Vaccines: 2018. Clin Pharmacol Ther | Vol. 2018;104(6). https://doi.org/10.1002/cpt.1208

[10]. Surenaud $M$, Montes $M$, Lindestam Arlehamn CS, Sette $A$, Banchereau J, Palucka K, et al. Anti-HIV potency of T-cell responses elicited by dendritic cell therapeutic vaccination. PLoS Pathog. 2019; https://doi.org/10.1371/journal.ppat.1008011

[11]. Norton TD, Zhen A, Tada T, Kim J, Kitchen S, Landau NR. Lentiviral Vector-Based Dendritic Cell Vaccine Suppresses HIV Replication in Humanized Mice. Mol Ther. 2019;27(5):960-73. https://doi. org/10.1016/i.ymthe.2019.03.008

[12]. Maartens G, Celum C, Lewin SR. HIV infection: Epidemiology, pathogenesis, treatment, and prevention. In: The Lancet. 2014. https://doi.org/10.1016/S0140-6736(14)60164-1

[13]. Budiarti R. HIV Infection: Immunopathogenesis and Risk Factor to Fishermen. Ocean Biomed J. 2018; https://doi.org/10.30649/obj. v1i1.4

[14]. Fletcher C V, Staskus K, Wietgrefe SW, Rothenberger M, Reilly C, Chipman JG, et al. Persistent HIV-1 replication is associated with lower antiretroviral drug concentrations in lymphatic tissues. Proc Natl Acad Sci U S A. 2014; https://doi.org/10.1073/pnas.1318249111

[15]. Chacko JB, Sankar GRV. Lymphatic targeted drug delivery systems and its application to HIV treatment; a review. International Journal of Pharmaceutical Research. 2020. https://doi.org/10.31838/ ijpr/2021.13.01.085

[16]. Smith LK, Babcock IW, Minamide LS, Shaw AE, Bamburg JR, Kuhn TB. Direct interaction of HIV gp120 with neuronal CXCR4 and CCR5 receptors induces cofilin-actin rod pathology via a cellular prion protein-And NOX-dependent mechanism. PLoS One. 2021; https:// doi.org/10.1371/journal.pone.0248309

[17]. Swanstrom R, Coffin J. HIV-1 pathogenesis: The virus. Cold Spring Harb Perspect Med. 2012; https://doi.org/10.1101/cshperspect. $\underline{\mathrm{a} 007443}$

[18]. Ford N, Meintjes G, Vitoria M, Greene G, Chiller T. The evolving role of CD4 cell counts in HIV care. Current Opinion in HIV and AIDS. 2017. https://doi.org/10.1097/COH.0000000000000348

[19]. Sabado RL, Balan S, Bhardwaj N. Dendritic cell-based immunotherapy. Cell Research. 2017. https://doi.org/10.1038/cr.2016.157

[20]. Gorry PR, Ancuta P. Coreceptors and HIV-1 pathogenesis. Current HIV/AIDS Reports. 2011. https://doi.org/10.1007/s11904-0100069-X

[21]. Kristoff J, Rinaldo CR, Mailliard RB. Role of dendritic cells in exposing latent HIV-1 for the kill. Viruses. 2019. https://doi.org/10.3390/ v12010037

[22]. Mathan TSM, Figdor CG, Buschow SI. Human plasmacytoid dendritic cells: From molecules to intercellular communication network. Frontiers in Immunology. 2013. https://doi.org/10.3389/ fimmu.2013.00372

[23]. Reizis B. Classical dendritic cells as a unique immune cell lineage. Journal of Experimental Medicine. 2012. https://doi.org/10.1084/ jem.20121038
[24]. Marin M, Kushnareva Y, Mason CS, Chanda SK, Melikyan GB. HIV1 Fusion with CD4+ T cells is promoted by proteins involved in endocytosis and intracellular membrane trafficking. Viruses. 2019; https://doi.org/10.3390/v11020100

[25]. Martín-Moreno A, Muñoz-Fernández MA. Dendritic cells, the double agent in the war against hiv-1. Frontiers in Immunology. 2019. https://doi.org/10.3389/fimmu.2019.02485

[26]. Barroca P, Calado M, Azevedo-Pereira JM. HIV/Dendritic cell interaction: Consequences in the pathogenesis of HIV infection. AIDS Reviews. 2014.

[27]. Smith P, Norgate K, Hegarty E, Gregeda N, Heelas E, Sommerfelt M, et al. Effect of the Modification of p24 Peptide Antigen on Dendritic Cell Uptake and T Cell Activation. Curr HIV Res. 2016; $\underline{\text { https://doi.or }}$ $\mathrm{g} / 10.2174 / 1570162 \times 13666161129115804$

[28]. Kastenmüller W, Kastenmüller K, Kurts C, Seder RA. Dendritic celltargeted vaccines-hope or hype? Nature Reviews Immunology. 2014. https://doi.org/10.1038/nri3727

[29]. Kulkarni V, Rosati M, Valentin A, Ganneru B, Singh AK, Yan J, et al. HIV-1 p24gag Derived Conserved Element DNA Vaccine Increases the Breadth of Immune Response in Mice. PLoS One. 2013; https:// doi.org/10.1371/journal.pone.0060245

[30]. Lee C, Lee M, Rhee I. Distinct features of dendritic cell-based immunotherapy as cancer vaccines. Clinical and Experimental Vaccine Research. 2018. https://doi.org/10.7774/cevr.2018.7.1.16

[31]. Zhang L, Wang W, Wang S. Effect of vaccine administration modality on immunogenicity and efficacy. Expert Review of Vaccines. 2015. https://doi.org/10.1586/14760584.2015.1081067

[32]. García F, Routy JP. Challenges in dendritic cells-based therapeutic vaccination in HIV-1 infection. Workshop in dendritic cellbased vaccine clinical trials in HIV-1. Vaccine. 2011. https://doi. org/10.1016/i.vaccine.2011.07.043

[33]. Zhao C, Ao Z, Yao X. Current advances in virus-like particles as a vaccination approach against HIV infection. Vaccines. 2016. https:// doi.org/10.3390/vaccines4010002

[34]. Miller E, Bhardwaj N. Dendritic cell dysregulation during HIV1 infection. Immunol Rev. 2013;254(1):170-89. https://doi. org/10.1111/IMR.12082

[35]. S. Waters R, Perry JSA, Han SP, Bielekova B, Gedeon T. The effects of interleukin-2 on immune response regulation. Math Med Biol. 2018; https://doi.org/10.1093/imammb/dqw021

[36]. Macatangay BJC, Riddler SA, Wheeler ND, Spindler J, Lawani M, Hong F, et al. Therapeutic Vaccination with Dendritic Cells Loaded with Autologous HIV Type 1-Infected Apoptotic Cells. J Infect Dis. 2016;213(9):1400-9. https://doi.org/10.1093/infdis/jiv582

[37]. García F, Plana M, Climent N, León A, Gatell JM, Gallart T. Dendritic cell based vaccines for HIV infection: The way ahead. Human Vaccines and Immunotherapeutics. 2013. https://doi.org/10.4161/ hv.25876

[38]. Gay CL, Debenedette MA, Tcherepanova IY, Gamble A, Lewis WE, Cope AB, et al. Immunogenicity of AGS-004 Dendritic Cell Therapy in Patients Treated during Acute HIV Infection. AIDS Res Hum Retroviruses. 2018;34(1):111-22. https://doi.org/10.1089/ aid. 2017.0071

[39]. Da Silva LT, Da Silva WC, De Almeida A, Da Silva Reis D, Santillo BT, Rigato PO, et al. Characterization of monocyte-derived dendritic cells used in immunotherapy for HIV-1-infected individuals. Immunotherapy. 2018;10(10):871-85. https://doi.org/10.2217/ imt-2017-0165

[40]. Gay CL, Kuruc JD, Falcinelli SD, Warren JA, Reifeis SA, Kirchherr $J \mathrm{~L}$, et al. Assessing the impact of AGS-004, a dendritic cell-based immunotherapy, and vorinostat on persistent HIV-1 Infection. Sci Rep. 2020;10(1):1-13. https://doi.org/10.1038/s41598-02061878-3. 